\title{
PEMBELAJARAN KONTEKSTUAL DALAM KEGIATAN BAHTSUL MASAIL SANTRI DI PONDOK PESANTREN AL-MUHIBBIN BAHRUL ULUM TAMBAKBERAS JOMBANG
}

\author{
M. Syarif Hidayatulloh \\ Universitas Maarif Hasyim Latif Sidoarjo \\ Syarif_hidayatulloh@dosen.umaha.ac.id
}

\begin{abstract}
Abstrak
Pesantren adalah lembaga pendidikan Islam tertua di Indonesia yang tumbuh-kembangnya seiring dengan perkembangan agama Islam di Indonesia. Bahstul masail adalah salah satu metode pembelajaran yang terdapat di lingkungan pesantren. Metode ini mendidik siswa/santri untuk berlatih berfikir kritis, solutif dan kontekstual. Sementara pembelajaran kontekstual atau CTL (Contextual and Teaching Learning) adalah sebuah pendekatan pembelajaran modern yang menekankan siswa sebagai subyek belajar yang menggali dan mencari pengalamn sendiri untuk pendapatkan pengetahuan. Penelitian ini membahas tentang bagaimana proses kegiatan pembelajaran bahstul masail santri di pondok pesantren Al-Muhibbin Bahrul Ulum Tambakberas Jombang? Apakah kegiatan bahstul masail santri di pondok pesantren Al-Muhibbin Bahrul Ulum Tambakberas Jombang ini merupakan aplikasi dari pembelajaran kontekstual? Penelitian ini menggunakan metode kualitatif-deskriptif. Adapun sumber datanya; 1. Tertulis 2. Dokumentasi 3. Lapangan. Untuk teknik pengumpulan datanya melalui wawancara, partisipasi, dan dokumentasi. Adapaun hasil penelitian ini adalah kegiatan bahstul masail santri di pondok pesantren al-Muhibbin merupakan kegiatan ekstra yang bersifat ilmiah yang diikuti oleh semua tingkatan santri dan dilakukan setiap satu bulan sekali dengan tujuan melatih santri untuk menganalisa dan memberikan jawaban
\end{abstract}

Nazhruna: Jurnal Pendidikan Islam

Vol. 1 No 2 Agustus 2018. Issn: 2614-8013. Hal. 177-200 
atas persoalan hukum yang terjadi di masyarakat sekitar. Kedua, kegiatan bahstul masail ini merupakan bentuk implementasi metode pendekatan pembelajaran kontekstual.

Kata Kunci: Bahstul masail, pembelajaran kontekstual, kitab kuning

\begin{abstract}
Pesantren is the oldest Islamic education institution in Indonesia that grows and develops along with the development of Islam in Indonesia. Bahstul masail is one of the learning methods found in the pesantren environment. This method educates students to practice critical, solutive and contextual thinking. While contextual learning or CTL (Contextual and Teaching Learning) is a modern learning approach that emphasizes students as learning subjects who explore and seek their own experiences to gain knowledge. This study discusses about the process of learning activities including students at the Islamic boarding school Al-Mubibbin Babrul Ulum Tambakberas Jombang? Is the activity of the Islamic boarding school students at Islamic boarding school AlMubibbin Babrul Ulum Tambakberas Jombang an application of contextual learning? This study uses a qualitative-descriptive method. The data source; 1. Written 2. Documentation 3. Field. For data collection techniques through interviews, participation, and documentation. The results of this study are the activities of students in the al-Mubibbin Islamic boarding school is an extra scientific activity which is attended by all levels of students and is done once a month with the aim of training students to analyze and provide answers to legal problems that occur in the surrounding community. Second, the activity of masap bahstul is a form of implementation of contextual learning approach method
\end{abstract}

Keyword : bahstul masail, contextual learning, kitab kuning

\title{
Pendahuluan
}

Ghafur yang dikutip oleh Kadir $^{1}$ bahwa di era modern seperti ini, masih ditemukan sistem pendidikan yang lebih menonjolkan aspek teori. Kenyataan dilapangan menunjukkan bahwa pada umumnya siswa tidak mampu mengubungkan apa yang

${ }^{1}$ Abdul Kadir, 'Konsep Pembelajaran Kontekstual Di Sekolah', Dinamika Ilmu 13, no. 1 (1 June 2013): 18, https://doi.org/10.21093/di.v13i1.20. 
mereka dapat dibangku sekolah dengan bagaimana cara pemanfaatan pengetahuan dikehidupan sehari-hari. Hal ini merupakan akibat dari proses pembelajaran dimana siswa belum dapat menangkap makna dari apa yang mereka peroleh dari pembelajaran.

Seharusnya, desain kurikulum harus responsif terhadap dinamika sosial, relevan, tidak over load, konprehensif dan dapat mengakomodir pesatnya perkembangan teknologi serta keragaman kebutuhan. Secara mikro dituntut untuk melakukan inovasi dalam pembelajaran yang lebih memberdayakan potensi siswa, sehingga kualitas pendidikan terjamin karena, kualitas pembelajaran harus ditingkatkan untuk meningkatkan kualitas hasil pendidikan ${ }^{2}$

Saat ini metode pembelajaran konvensional masih mendominasi proses pembelajaran yang berlangsung di sekolahsekolah. Metode pembelajaran konvensional dicirikan dengan minimnya peran peserta didik dan dominannya peran pada guru, peserta didik dianggap sebagai obyek belajar sementara aktivitas belajar diartikan sebagai transfer of knowledge. Paradigma pembelajaran seperti ini, peserta didik dapat memperoleh angka yang tinggi namun miskin aplikasi dan secara afeksi menunjukkan perilaku yang bertentangan serta berujung pada rendahnya kualitas hasil belajar. Hal semacam ini bisa terjadi sebagai akibat dari rendahnya kualitas proses pembelajaran.

Kenyataan bahwa mayoritas siswa tidak mampu mengaitkan antara yang dipelajari dengan kehidupan nyata menunjukkan perlunya pendekatan kontekstual dalam pembelajaran. Hal ini disebabkan oleh pemahaman konsep akademi yang mereka peroleh hanyalah merupakan sesuatu yang abstrak ${ }^{3}$

Metode pembelajaran yang selama ini mereka terima hannyalah penonjolan tingkat hapalan dari sekian pokok bahasan, tetapi tidak diikuti dengan pemahaman atau pengertian yang mendalam yang

2 M. Furqon Hidayatullah, Pendidikan karakter: membangun peradaban bangsa (Surakarta: Yuma Pustaka, 2010), 1.

3 Mardini, 'Pengaruh Pembelajaran Kontekstual Dan Konvensional Terhadap Keterampilan Komunikasi Terapiutik Ditinjau Dari Tingkat Pengetahuan Awal.' (Universitas Sebelas Maret, 2008), 9. 
bisa diterapkan ketika mereka berhadapan dengan situasi baru dalam kehidupan $^{4}$

Salah satu bentuk ikhtiyar dalam rangka meningkatkan mutu pendidikan adalah dengan meningkatkan kualitas pembelajaran. Out put dari pendidikan ditentukan oleh proses pembelajaran. Berkenaan dengan hal ini, untuk menciptakan sumber daya manusia yang berkualitas, guru dalam mengajar dapat menggunakan beberapa metode pendekatan pembelajaran.

Diantara metode pendekatan pembelajaran yang digunakan oleh pakar pendidikan modern adalah dengan menggunakan metode pendekatan pembelajaran kontekstual. Contextual Teaching and Learning (CTL) atau pembelajaran kontekstual merupakan sebuah pendekatan pembelajaran yang bertujuan membantu siswa menemukan makna materi yang ia peroleh dan mengaitkanya antara materi yang dipelajari dengan kehidupan nyata sehari-hari, baik dalam lingkup keluarga, sekolah, masyarakat maupun warga negara. Landasan pemikiran pendekatan CTL berangkat dari teori belajar konstruktivis yang dikembangkan oleh Jean Piaget, Jerome Breuner, dan John Dewey, yaitu memusatkan proses pembelajaran pada perubahan perilaku peserta didik itu sendiri dan dialami langsung untuk membentuk konsep belajar dan memahami ${ }^{5}$

Menurut Rudiyanto ${ }^{6}$, CTL merupakan proses pembelajarn yang holistik yang memiliki tujuan membantu siswa untuk menangkap makna dari materi pelajaran yang diperolehnya dan mengaitkannya kedalam konteks kehidupan sehari-hari mereka (konteks sosial, pribadi dan kultural), sehingga siswa memiliki pengetahuan dan keterampilan yang secara fleksibel dapat diterapkan dari satu permasalahan ke permasalahan lainnya.

Sementara itu, keberadaan pembelajaran konvesional masih sering dijumpai di berbagai lembaga pendidikan khususnya pondok pesantren. Pondok pesantren adalah sebuah lembaga pendidikan

\footnotetext{
${ }^{4}$ Masnur Muslich, KTSP: pembelajaran berbasis kompetensi dan kontekstual, panduan bagi guru, kepala sekolah, dan pengawas sekolah (Jakarta: Bumi Aksara, 2007), 40.

${ }^{5}$ Tim Fasilitator Pelatihan Pekerti-AA Kopertis Wilayah VII. 2014. H. 112

6 Moh Rudiyanto, "'The Implementation of Contextual Teaching and Learning (CTL) in English Class', Jurnal OKARA 2 (2009): 232.
} 
Islam berbasis masyarakat yang menyelenggarakan pendidikan diniyyah dengan memadukan jenis pendidikan lainya, yang berorientasi pada pengembangan pengetahuan, kemampuan serta ketrampilan siswa / santri dengan harapan menjadi ahli agama sekaligus memiliki keterampilan (soft skill) atau keahlian dalam membangun kehidupan yang islami di masyarakat ${ }^{7}$.

Salah satu ciri khas pesantren ada pada sistem pembelajaranya yakni sorogan kitab klasik atau yang sering disebut kitab kuning. Dan hal ini adalah sebuah tradisi khas pesantren dan dirasa perlu dipertahankan. Karena kelak output pesantren yang pasti akan bersinggungan dengan masyarakat, harus tetap membiasakan diri mengkaji dan memahami isi kitab kuning agar tidak salah dalam memberikan jawaban atau pengertian tentang suatu hal bersifat keagamaan kepada masyarakat luas ${ }^{8}$

Tradisi pengajian kitab kuning ini dapat disebut sebagai salah satu unsur dasar dari tumbuh dan berkembangnya forum kegiatan bahtsul masail. Sebab, dalam kajian babtsul masail rujukan untuk mencari solusi atas problem yang menjadi kajian harus kembali pada kitab-kitab yang telah di standarisasi oleh para ulama sebagai kitab baku, yang sebagian besar berupa kitab kuning.

Pondok pesantren Al-Muhibbin Bahrul 'Ulum Tambakberas Jombang merupakan pondok yang didalamnya terdapat kegiatan bahstul masail yang dilakukan oleh para santri. Pilihan pondok AlMuhibbin sebagai obyek dikarenakan letak pondok ini berada di wilayah kota jombang dimana banyak pondok salaf didalamnya. Dalam penelitian ini peneliti fokus terhadap kegiatan bahstul masail santri apakah kegiatan tersebut merupakan bentuk pembelajaran dengan menggunakan pendekatan kontekstual atau contextual teaching learning (CTL).

7 Irfan Paturohman, Peran Pendidikan Pondok Pesantren Dalam Perbaikan Kondisi Keberagamaan Di Lingkungannya.(Studi Deskriptif Pada Pondok Pesantren Dar Al-Taubah Bandung)', Jurnal Tarbawi 1, no. 1 (2012): 65.

8 Alfi Najmatil Ilmy, Abd Hamid Wahid, and Chusnul Muali, 'Urgensi Keterlibatan Wali Asuh Dalam Dinamika Pendidikan Di Pesantren', Jurnal Pendidikan Agama Islam (Journal of Islamic Education Studies) 6, no. 1 (17 July 2018): 48, https://doi.org/10.15642/jpai.2018.6.1.44-66. 
Penelitian ini menggunakan kualitatif yang lebih menitik beratkan pada perilaku, kata-kata dan alami analisis datanya menggunakan deskriptif. Sebagaimana yang di jelaskan oleh J. Moleong 9 yang mengutip dari bogdan dan taylor ${ }^{10}$ bahwa penelitian kualitatif adalah prosedur penelitian yang menghasilkan data deskriptif berupa kata-kata tertulis atau lisan dari orang-orang dan perilaku yang dapat diamati. Metode pengumpulan data nya dengan menggunakan observasi, wawancara, dokumentasi dan catatan lapangan.

\section{.Hasil Penelitian}

\section{Aktivitas Pendidikan di pondok Pesantren Al-Muhibbin}

a. Madrasah Diniyah

Madrasah diniyah yang terdapat di pesantren alMuhibbin merupakan lembaga khusus yang menangani pendidikan yang bertujuan untuk meningkatkan mutu dan kualitas pendidikan serta wawasan intelektual dikalangan santri al-Muhibbin. Melalui madrasah diniyah ini santri dibimbing dan dibina untuk sedapat mungkin menguasai dan memahami isi dari kitab kuning yang sesuai dengan ajaran ahlissunnah wal jama'ah.

Dikarenakan semua santri yang berdomisili di pesantren Al-Muhibbin adalah siswa dari unit-unit sekolah formal di lingkungan pondok pesantren Bahrul Ulum (MI, MTs, MA, Mu'allimin) maka jenjang madrasah diniyyah disesuaikan dengan jenjang sekolah santri, adapun perinciannya adalah sebagai berikut :

1. Kelas Ula : Untuk siswa Madrasah Tsanawiyah.

2. Kelas Ula PK : Untuk siswa Madrasah Ibtidaiyah kelas 5 dan 6.

3. Kelas Wustho : Untuk siswa Madrasah Aliyah yang berasal dari SMP / MTs luar

9 Moloeng Lexy J, Metodologi penelitian Kualitatif, 29th ed. (Bandung: Rosdakarya, 2011), 4.

10 Steven J. Taylor, Robert Bogdan, and Marjorie L. DeVault, Introduction to Qualitative Research Methods: A Guidebook and Resource, Fourth edition (Hoboken, New Jersey: John Wiley \& Sons, Inc, 2016), 4. 
4. Kelas Wustho PK: Untuk siswa Madrasah Aliyah yang berasal dari MTs Bahrul Ulum

5. Kelas Ulya : Untuk siswa Madrasah Mu'allimin Mu'allimat.

6. Pasca Diniyah : Untuk siswa yang telah lulus dari madrasah diniyyah Al Muhibbin.

Jenjang Ula, Wustho dan Ulya semuanya ditempuh dalam waktu tiga tahun. Dari pembagian kelas yang ada dapat difahami bahwa Madrasah diniyyah Al Muhibbin menggunakan model Klasikal, yakni dengan membuat dan menentukan tingkatan kelas diniyyah berdasarkan kelas sekolah formal.

b. Pengajian Wethon

Untuk pengaiian wethon dilaksanakan Ba'da Jama'ah Sholat Ashar (secara sentral di Masjid) dan ba'da shubuh (di ndalem pengasuh) oleh pengasuh Bumi Damai Al Muhibbin yakni KH. M. Idris Djamaluddin, adapun kitab yang di kaji adalah :

\section{Ibya' Ulumiddin}

2. Ummul Barobin

3. Fathul Mu'in

c. Pengajian Al-Hikam

Pengajian ini dilaksanakan setiap hari senin malam selasa ba'da isya' di masjid Bumi Damai Al Muhibbin dan disampaikan langsung oleh Romo KH. M. Djamaluddin Ahmad. Pada mulanya pengajian ini hanya diikuti oleh beberapa orang saja, lama kelamaan jama'ah pengajian ini semakin bertambah, dan saat ini jama'ah pengajian ini hampir mencapai 2000 orang yang terdiri dari para santri, alumni dan masyrakat umum baik yang berasal dari daerah jombang sendiri maupun daerah luar Jombang seperti Mojokerto, Sidoarjo, Nganjuk, Kertosono, Tuban dan daerah-daerah lain.

d. Pengajian Ahad Legi

Pengajian ini dilaksanakan satu bulan sekali setiap hari Ahad Legi yang diikuti oleh jama'ah ibu-ibu yang ada 
dilingkungan kota Jombang dan sekitarnya. Saat ini jama'ah yang ikut dalam pengajian ini sekitar 500 orang jama'ah.

\section{Metode Pengajaran}

Sebagai institusi pendidikan Islam tertua di Indonesia, pesantren dikenal dengan institusi yang mempertahankan tradisi pembelajaran dan sistem pendidikan yang sudah dikenal sejak periode awal Islam masuk ke Indonesia. Sistem pendidikan yang terdapat di pesantren terdiri dari beberapa komponen; pertama, berkaitan dengan metode pembelajaran, kedua, berkaitan dengan bahan ajar dan sumber belajar. untuk metode pembelajaran sendiri terdapat beberapa metode yang hingga saat ini masih dipertahankan di pesantren yaitu: sorogan, bandongan, wetonan, dan lainnya. Sedangkan berkaitan dengan bahan ajar dan sumber belajar, kitab kuning adalah bahan dan sumber belajar bagi santri yang tak pernah terlupakan dan tak tergantikan dalam proses pembelajaran di pesantren ${ }^{11}$

Begitu pula sistem pengajaran yang digunakan di pondok pesantren Al-Muhibbin juga meliputi:

\section{a). Sistem Wethon}

Zamakhsyari Dhofier ${ }^{12}$ menerangkan bahwa metode wethon adalah suatu metode pengajaran dimana seorang ustad atau kyai membaca, menterjemahkan, menerangkan, dan mengulas kitab-kitab klasik dalam yang ditulis menggunakan bahasa Arab sementara santri mendengarkannya. Mereka memperhatikan kitabnya sendiri dan membuat catatan sederhana tentang kata-kata atau buah pikiran yang sulit. Menurut Nur Hasan ${ }^{13}$, wethon merupakan sebuah istilah yang berasal dari bahasa Jawa yang memilki arti waktu. Dikatakan

11 Akh Syaiful Rijal, 'Pemakaian Kitab Kuning Dalam Meningkatkan Mutu Pembelajaran Fiqh Di Madrasah Tsanawiyah Berbasis Pesantren Di Pamekasan', Muslim Heritage 2, no. 2 (1 January 2018): 294, https://doi.org/10.21154/muslimheritage.v2i2.1113.

12 Zamakhsyari Dhofier, Tradisi pesantren: studi pandangan hidup kyai dan visinya mengenai masa depan Indonesia, Cet. 8 rev (Jakarta: LP3ES, 2011), 143.

13 Nur Hasan, 'Model Pembelajaran Berbasis Pondok Pesantren Dalam Membentuk Karakter Siswa Di Pondok Pesantren Raoudhotut Tholibin Rembang Jawa Tengah', Wahana Akademika: Jurnal Studi Islam Dan Sosial 3, no. 2 (2016): 97. 
demikian karena pembelajaran dengan menggunakan metode ini dilakukan oleh santri pada waktu-waktu tertentu, seperti setelah melaksanakan shalat fardlu dan dilakukan seperti kuliah terbuka yang diikuti para santri dan selanjutnya kiai membaca, menerjemahkan, menerangkan, sekaligus mengulas kitab-kitab salaf yang menjadi acuan. Termasuk dalam pengertian weton adalah halaqah.

Dalam sistem ini pihak yang aktif adalah guru, dalam prakteknya sekelompok murid mendengarkan seorang guru membaca, menerjemah, menerangkan dan mengulas isi dari kitab-kitab yang berbahasa arab (kitab kuning) sedangkan para murid memperhatikan dan membuat catatan-catatan (baik arti maupun keterangan) tentang kata-kata atau buah pikiran yang dianggap sulit di fahami. Sistem ini sering digunakan dalam menyampaikan materi Fiqh dan Tauhid.

\section{b). Sistem Sorogan}

Sedangkan metode sorogan merupakan suatu metode yang ditempuh dengan cara guru menyampaikan pelajaran kepada santri secara individual. Dalam sistem ini pihak yang aktif adalah murid, dalam prakteknya murid membaca al Qur'an atau kitab-kitab berbahasa arab (kitab kuning) dihadapan gurunya dengan memperhatikan panjang pendek bacaan, makhorijul huruf atau harokat dan maknanya (makna pego/jawa) sedangkan guru menyimak dengan seksama dan membenarkan apabila terdapat bacaan yang salah dari murid. Sistem ini dipakai dalam materi baca kitab dan al Qur'an.

Termasuk di pesantren Al-Muhibbin, santri yang masih pada tingkat pemula yakni baru belajar al-qur'an maupun kitab kuning metode yang digunakan adalah menggunakan metode sorogan. Karena dengan metode ini, kiai atau ustadz dapat mengetahui perkembangan intelektual secara utuh. Santri mendapat bimbingan langsung dari ustadz dengan penuh kejiwaan sehingga sang ustadz dapat memberikan tekanan pengajaran kepada santri tertentu yang didasari observasi 
langsung terhadap tingkat kemampuan dasar dan kapasitas mereka.

\section{c) Sistem Muhafadzoh}

Dalam sistem ini setiap murid harus menghafal materi pelajaran yang telah ditentukan oleh guru kemudian menyetorkan hafalan tersebut kepada guru. Sistem ini digunakan pada materi-materi ilmu alat (gramatika arab) seperti shorof dan nahwu.

\section{Kegiatan Ekstrakulikuler}

Kegiatan ekstra ini meliputi dua hal: pertama yang bersifat ubudiyyah atau keagamaan yang berupa amaliah-amaliah diniyyah dan kedua, intelektualitas yang dilakukan dalam bentuk kajian-kajian. Adapaun perincianya sebagai berikut:

a. Keagamaan

1). Dzibaiyyah

Target

- Mampu membaca Dziba'

- Mampu mengeksplor kreatifitas dalam permainan nada

- Mampu hikmad dalam setiap pembacaan Dziba' Waktu

- Malam Jumat,Ba'da Isya' ( \pm 19.45 s.d. 21.00 Wib)

2.) Manaqib Target

- Mampu membaca manaqib

Waktu

- Malam Jumat, Ba'da Isya' ( \pm 19.45 s.d. 21.00 Wib)

3). Ziarah Makam

Waktu

-Jumat, Ba'da subuh (05.00 s.d. selesai) Tempat

- Makam Ibu Hj. Churriyah Djamaluddin dan Masyayikh Bahrul 'Ulum

a. Intelektualitas

Tabel. 1 


\begin{tabular}{|c|c|c|c|c|}
\hline No & $\begin{array}{c}\text { Jenis } \\
\text { kegiatan }\end{array}$ & Model & Contoh kegiatan & Waktu \\
\hline 1. & Pembekalan & $\begin{array}{l}\text { Pengajian oleh } \\
\text { satu } \\
\text { narasumber } \\
\text { tanpa } \\
\text { moderator } \\
\text { tentang kajian- } \\
\text { kajian praktis } \\
\text { keagamaan }\end{array}$ & $\begin{array}{l}\text { Ke-Aswaja-an, } \\
\text { Manasik Haji, } \\
\text { Tajhizul Janazah, } \\
\text { dll. }\end{array}$ & $\begin{array}{ll}\text { Malam } & \text { Jumat } \\
\text { satu } & \text { bulan } \\
\text { sekali } & \end{array}$ \\
\hline 2. & Halaqoh & $\begin{array}{l}\text { Diskusi Panel } \\
\text { dan moderator }\end{array}$ & $\begin{array}{l}\text { Diskusi mahasiswa } \\
/ \quad \text { santri yang } \\
\text { sudah } \\
\text { menyelesaikan } \\
\text { tingkat Ulya }\end{array}$ & Hari efektif \\
\hline 3. & $\begin{array}{l}\text { Bahtsul } \\
\text { Masa'il }\end{array}$ & - & - & $\begin{array}{l}\text { Setiap satu } \\
\text { bulan sekali }\end{array}$ \\
\hline
\end{tabular}

\section{Urgensi Bahtsul Masa'il Bagi Santri Al-Muhibbin}

Menurut saleh ${ }^{14}$ bahwa dalam praktik pendidikan modern, terbukti tidak efektif ketika proses pembelajaran hanya menjejali pikiran siswa dengan bermacam teori dan konsep tanpa dibarengi dengan pengalaman. Misalnya dibidang kedokteran, mahasiswa yang disibukkan hanya dengan menghafal berbagai teori dan konsep penanganan penyakit, akan merasa kesulitan ketika menghadapi masalah di dunia nyata, seringkali teori yang dikuasai dengan baik belum menjamin dapat diterapkan sepenuhnya atau minimal cara mengatasinya kurang tepat, karena realita dilapangan yang dihadapi sangat bervariasi.

Kompleksitas persoalan-persoalan baru yang muncul ditengah masyarakat membutuhkan pemecahan agar memberikan jalan dan pegangan bagi masyarakat awam tentang status hukum dari sebuah

14 Marhamah Saleh, 'Strategi Pembelajaran Figh Dengan Problem-Based Learning', Jurnal Ilmiah Didaktika: Media Ilmiah Pendidikan Dan Pengajaran 14, no. 1 (1 August 2013): 192, https://doi.org/10.22373/jid.v14i1.497. 
persoalan, sehingga mereka tidak salah dalam mengamalkan amalan yang belum jelas hukumnya.

Secara historis, kegiatan bahstul masail tidak bisa dipisahkan dengan keberadaan pondok pesantren. Bagi pondok pesantren salaf khususnya yang ada di Jawa dan Madura kegiatan ini merupakan kegiatan rutin yang diberlakukan dikalangan santri. Kegiatan babtsul masail telah berkembang di masyarakat muslim tradisionalis pesantren yang kemudian diresmikan menjadi lembaga bagian dari organisasi keagamaan Nahdlatul Ulama dalam Muktamar NU ke XXVII di Yogyakarta pada tahun $1989^{15}$

Dijelaskan dalam butir F pasal 16 Anggaran Dasar dan Anggaran Rumah Tangga NU menyebutkan bahwa tugas bahtsul masail adalah menghimpun, membahas dan memecahkan masalah masalah yang mauquf dan waqi"iyah yang harus segera mendapat kepastian hukum (ADART NU, 1994: 3).

Istilah Bahtsul masâil yang berarti pembahasan masalah merupakan istilah yang sangat familiar dengan pondok pesantren tradisional di Indonesia, Istilah ini menunjuk pada sebuah forum kajian ilmiah antar santri dalam memecahkan berbagai masalah keagamaan yang menghasilkan produk hukum (fiqh).

Bahtsul Masa'il santri selain untuk membentuk karakter santri dan ukhuwah islamiyah, juga untuk mengembangkan sikap tenggang rasa dan keberanian mengemukakan pendapat dan pendirian masing-masing anggota Bahtsul Masa'il ${ }^{16}$

Disamping itu, tujuan kegiatan Bahtsul Masa'il untuk mengajarkan kepada para santri untuk memecahkan problematika sosial-keagamaan dengan merujuk pada pendapat abli fikih yang terdokumentasikan dalam bentuk kitab kuning. Sekaligus untuk mebiasakan mereka bagaimana cara mengungkapkan argumentasi yang ilmiah.

15 Ahmad Zahro, Tradisi Intelektual NU: Lajnah Babtsul Masa'il, 1926-1999, Cet. 1 (Yogyakarta: LKiS, 2004), 58.

16 PWNU JATIM, Petunjuk Pelaksanakan Babtsul Masa’il. (Surabaya: PWNU, 1982), 182. 
Dalam rangka mencari jawaban atas persoalan hukum yang diajukan, diskusi dapat dianggap selesai jika para peserta menemukan dalil eksplisit yang sesuai dengan permasalahan dimaksud dalam satu atau beberapa kitab yang mu'tabar. Meski ketika proses kajian seringkali terjadi perdebatan tentang berbagai hal yang berkaitan dengan permasalahan yang dibahas, akan tetapi rumusan jawaban yang telah disepakati oleh mubahistin pada akhirnya didokumentasikan dan dipublikasikan yang isinya tidak lebih dari sah - batal nya sesuatu atau halal-haramnya sesuatu disebabkan keberadaan teks dalam kitab tertentu yang menyatakan demikian.

Yang menjadi acuan dalam bahstul masail adalah pemecahan masalah yang berhubungan dengan hukum Islam (fiqh). Topik atau materi yang diangkat dalam forum ini bervariasi dan mencakup permasalahan terkini. Dalam membahas masalah-masalah aktual peserta mengkaji bagaimana pandangan islam terhadap masalah tersebut ${ }^{17}$. Dalam pelaksanaanya, para santri diberi ruang untuk mengklarifikasi soalan yang diajukan kepada mereka melalui pertanyaan-pertanyaan dan mereka juga diberi keluasan mengemukakan pendapatnya. Dengan ini, kegiatan Babtsul Masa'il lebih menekankan pada kualitas individu dalam menganalisis dan memecahkan suatu persoalan dengan argument logika yang mengacu pada kitab-kitab tertentu.

Ada beberapa komponen yang terlibat dalam kegiatan bahstul masail, diantaranya adalah; mubahistin (peserta), moderator, mushobih (para ahli yang mentashib jawaban), muharrir (orang yang merumuskan jawaban), notulen dan beberapa panitia. Setiap komponen tersebut memiliki wewenang sendiri-sendiri dan aturan yang jelas. Wewenang dan aturan tersebut menurut M. Ridlwan Qayyum Sa ${ }^{e e} i d^{18}$ adalah:

1. Moderator

Moderator mempunyai beberapa wewenang, yaitu:

a. Memimpin jalannya bahstul masail, menjaga ketertiban, mengatur dan membagi waktu.

17 M. Amin Haedari, ed., Masa Depan Pesantren: Dalam Tantangan Modernitas Dan Tantangan Kompleksitas Global, Cet. 2 (Jakarta: IRD Press, 2006), 100.

${ }^{18}$ Haedari, 61-63. 
b. Memberi izin, menerima usul dan pendapat mubahistin.

c. Memberi kesempatan kepada nara sumber untuk mendeskripsikan masalah sesuai permintaan mubabistin.

d. Memilih peserta untuk merespon masalah.

e. Memberi kesempatan kepada peserta yang lain yang memilki pendapat dan rujukannya berbeda untuk menanggapi dengan mencari kelemahan ibarat-nya.

f. Mengarahkan pembahasan yang menyimpang dari topik kajian.

g. Membacakan jawaban yang telah disepakati dan disimpulkan oleh tim perumus untuk kemudian dikembalikan lagi pada para peserta.

h. Mengetuk tiga kali sebagai tanda bahwa rumusan jawaban telah disepakati dan meminta kepada musohbih untuk memimpin bacaan surat al-Fatihah bersama-sama sebagai simbol pengesahan.

i. Menunjuk peserta lain untuk menggantikan peserta yang meninggalkan forum dalam keadaan dlorurot.

j. Mampu mendeskripsikan alur dan kronologi permasalahan yang akan di bahas.

k. Tegas dan sopan kepada mubahitsin, perumus maupun mushobih. Seorang Moderator juga mempunyai beberapa larangan, diantaranya :

a. Ikut memberikan argumen

b. Tidak obyektif atau memihak salah satu peserta

c. Mengintervensi peserta

2. Mubarrir (Perumus)

Wewenang tim perumus (dewan mubarrir) adalah:

a. Mengakomodir jawaban dan ta" bir yang masuk.

b. Memilah ta"bir sesuai dengan kajian yang dibahas.

c. Mengarahkan jawaban peserta jika menyimpang.

d. Membuat rumusan jawaban.

e. Mengikuti jalannya acara bathsul masail.

Adapun larangan bagi tim perumus adalah :

a. Mengajukan jawaban yang tidak disertai ta"bir dari peserta. 
b. Mengemukakan pendapat tanpa persetujuan moderator.

c. Berpendapat diluar pembahasan.

d. Melakukan aktivitas yang dapat menggangu konsentrasi peserta; marah, tidur, dan senda gurau.

e. Meninggalkan ruangan sebelum kegiatan berakhir.

3. Mushobih

Mushohih memilki tanggungjawab sebagai berikut:

a. Hadir dan mengikuti kegiatan bahstul masail dari awal hingga selesai.

b. Memberikan saran, masukan dan pengarahan kepada mubahistin.

c. Memberikan pertimbangan dan men tashib (mengesahkan) hasil keputusan bahtsul masail dengan memimpin bacaan surat al-Fatihah

Adapun larangan bagi mushobih adalah:

a. Mengesahkan dengan bacaan surat al-Fatihah sebelum ada kesepakatan.

b. Meninggalkan forum sebelum waktunya kecuali ada uədur (halangan).

4. Peserta

Mubahistin atau peserta memiliki wewenang sebagai berikut:

a. Datang sepuluh menit sebelum dimulai dan menempati tempat yang disediakan panitia.

b. Memberikan respon terhadap masalah yang diajukan oleh sail (penanya).

c. Menjawab dan menunjukkan ibarat-nya setelah diberi waktu oleh moderator.

d. Menyerahkan ibarat (teks) nya kepada mubarrir (tim perumus).

e. Menghargai dan menghormati pendapat orang lain.

Adapun larangan bagi peserta adalah:

a. Meninggalkan forum dengan tanpa seizin moderator.

b. Melakukan aktivitas yang menimbulkan gaduh dalam forum bahtsul masail.

c. Berseteru pendapat sesama delegasi. 
d. Debat kusir dengan peserta lain atau tanpa melalui. Hak suara bagi peserta adalah:

a. Melalui moderator peserta memiliki hak menolak dan menyanggah argumentasi atau jawaban yang diajukan peserta lain.

b. Melalui moderator peserta berhak memberikan usulan, tanggapan dan argumentasinya selama forum bahstul masail berlangsung.

c. Peserta diberi hak untuk mengoreksi rumusan jawaban yang telah dirumuskan oleh muharrir.

Sementara dalam pengambilan keputusan, jawaban atau ta'bir yang diajukan oleh peserta dapat disahkan dan diputuskan apabila telah disetujui oleh mubahitsin, mubarrir dan mushobih melalui kesepakatan bersama. Dan apabila selama proses kegiatan bahstul masail berlangsung sementara masalah tidak dapat di selesaikan baik oleh mubabitsin, perumus, dan mushobih serta tidak berkenan untuk melanjutkan pembahasan maka jawaban dianggap manquf yakni tidak ditemukannya jawaban dari masalah yang dikaji. Namun, jika terdapat dua pendapat yang berbeda, maka sepenuhnya diserahkan kepada kebijakan moderator atas restu mubarrir dan mushobih. Keputusan yang telah ditetapkan dalam forum bahtsul masail dianggap sah dan tidak bisa diganggu gugat kecuali melalui forum yang sama atau lebih tinggi ${ }^{19}$

Atas dasar proses dan prosedur ini, sejak dini santri diajari untuk menghormati berbagai pendapat yang berbeda serta menerima masukan dan usulan dari orang lain. Dari sini, santri memiliki sikap toleran terhadap sikap dan argumen orang lain, selama pendapat tersebut ditopang dengan ta'bir yang kuat. Perbedaan pendapat dalam tingkat wacana ini pada gilirannya diharapkan dapat mempengaruhi sikap dan cara berfikir santri atas perbedaan yang ada muncul sekitar mereka.

19 Said Aqiel Siradj et al., eds., Pesantren Masa Depan: Wacana Pemberdayaan Dan Transformasi Pesantren, Cet. 1 (Bandung: Pustaka Hidayah, 1999), 64. 


\section{Bahtsul Masa'il Sebagai Implementasi Pembelajaran Kontekstual}

Di sebagian pondok pesantren (salaf) kegiatan bahtsul masail merupakan bagian dari kegiatan ekstrakulikuler termasuk di pondok AlMuhibbin Bahrul Ulum Tambakberas Jombang. Artinya, pelaksanaanya diluar jam pembelajaran efektif dan santri pada tingkat tertentu yang terlibat dalam kegiatan tersebut. Dalam pelaksanaanya, kegiatan bahstul masail ini di kelola sendiri oleh pengurus pondok yang sudah tersusun struktur kepengurusan yang khusus menangani kegiatan bahstul masail.

Menurut Badrus salam (06 Juni 2011) kegiatan ini adalah untuk mendidik santri agar dapat mencari ibarat dari berbagai kitab klasik untuk menjawab soalan-soalan yang diajukan oleh sail. Kegiatan ini terbukti dapat menghasilkan santri-santri yang mampu menjawab soalan-soalan kontemporer dengan landasan hasil ijtihad ulama. Jadi, kegiatan bahtsul masail ini tidak lain adalah sebuah forum untuk menentukan status hukum bagi persoalan kontemporer yang sifatnya ittiba' kepada ulama. Selain itu kegiatan bahtsul masail yang diadakan di pondok pesantren juga untuk melatih para santri untuk menganalisa masalah - masalah waqi'iyyah berikut solusinya. Masalah waqi'iyyah adalah masalah-masalah kontemporer yang sedang berkembang di masyarakat. Misalnya terkait hukum imunisasi yang merupakan program pemerintah.

Model Bahtsul Masail ala pesantren pada umumnya mengedepankan semangat itiradl atau perdebatan argumentatif dengan berorientasi kepada kitab salaf atau buku-buku fiqih yang mu'tabarah (Najmudin, 2015: 54).

Peserta bahtsul masail ini adalah santri madrasah diniyah yang sudah pada tingkat ulya. Nantinya peserta Bahtsul Masail dibagi kedalam beberapa kelompok dan setiap kelompoknya terdiri dari tiga santri.

\section{Tahap Persiapan}

Secara teknis, menurut Iwan selaku penanggung jawab kegiatan (26 Juni 11) tahapan-tahapan kegiatan bahtsul masail di pondok AlMuhibbin Bahrul Ulum diawali dengan pendistribusian beberapa persoalan yang akan dibahas dengan skala prioritas soalan yang paling 
awal kepada peserta bahstul masail. Soalan yang diberikan oleh panitia kepada peserta babstul masail disertakan pula diskripsi masalah dan pertimbangan yang perlu dicermati oleh para peserta. Ini dikarenakan setiap persoalan memiliki karakter tersendiri, hal ini untuk memudahkan para peserta untuk mencari ibarah maupun dalil yang sesuai dengan persoalan yang diajukan oleh panitia.

Pengurus atau panitia menentukan jangka waktu sekitar 2-3 minggu kepada para peserta untuk persiapan mencari ibarah dan bujjah sebelum disampaikan saat kegiatan bahtsul masail. Masalah-masalah yang akan dibahas merupakan usulan dari para santri sendiri, asatidz, dan pengurus. Kadang juga menurut badrus (27 Juni 2011) masalahmasalah yang dibahas adalah persoalan masyarakat sekitar yang diajukan pada pengasuh pondok, hal ini termasuk salah satu motivasi bagi santri untuk melaksanakan bahtsul masail. Usulan masalah itu dikumpulkan dan disaring oleh panitia untuk menjadi tema pembahasan bersama dalam forum tersebut.

\section{Tahap Pelaksanaan}

Pada tahap ini, Iwan (26 Juni 2011) menjelaskan dalam Bahtsul Masa'il dibuka oleh moderator dan dilanjutkan penjelasan deskripsi masalah yang kemudian moderator memberi kesempatan kepada para peserta untuk menanyakan atas kejelasan masalah yang telah diajukan. Apabila diantara mubabistin ada meminta penjelasan lebih lanjut maka bisa langsung ditanyakan kepada sobibul sail / penanya yang memahami dan menguasai problematika yang dikaji. Setelah moderator mendiskripsikan dan menjelaskan permasalahan dan telah dipahami oleh peserta, moderator selanjutnya mempersilahkan kepada para peserta untuk melaksanakan pembahasan serta mengajukan jawabanya disertai dengan argumen dan dalil masing-masing. Dalil yang dikemukakan diambil dari kitab-kitab kuning yang mereka pelajari.

Apabila dalam proses bahstul masail mubabistin tidak mendapatkan titik temu terkait perbedaan jawaban, maka moderator mempersilahkan mubarir untuk memberikan arahan kepada mubahistin agar mencari titik temu. Setelah itu, moderator memberi kesempatan kepada peserta untuk melanjutkan diskusi dan meminta kepada mubarrir untuk merumuskan jawaban yang dilanjutkan oleh mushohih untuk 
memberikan komentar terhadap rumusan jawaban hasil diskusi tersebut. Rumusan jawaban yang telah dikomentari oleh Mushobih dan disepakati oleh mubahistin maka mushohih memimpin bacaan surat alFatihah sebagai tanda telah disahkannya produk hukum hasil bahtsul masail pada kegiatan tersebut.

Poin penting dalam kegiatan ini ialah waktu pendistribusian topik dan penetuan topik. Jika topik yang dikaji merupakan persoalan yang update dan menjadi isu keagamaan yang perlu ditemukan rumusan jawabannya dalam kitab kuning maka hal ini dapat memberikan rangsangan tersendiri kepada para santri untuk belajar serta dapat menambah antusias para santri saat diskusi berlangsung. Begitu pula, pendistribusian topik jauh-jauh hari lebih dimaksudkan agar para mubabistin dapat mempersiapkan dengan matang dan tepat terhadap pilihan ta'bir sebelum musyawarah itu dilaksanakan.

Berdasar tahapan- tahapan diatas dan sebagaimana yang dijelaskan kadir $^{20}$ bahwa pembelajaran kontekstual memiliki tujuh karakter tersendiri yang membedakan dari pendekatan pembelajaraan yang lain, peneliti dapat menyimpulkan bahwa kegiatan bahstul masail yang dilakukan oleh santri pondok Al-Muhibbin Bahrul Ulum Tambakberas Jombang merupakan sebuah bentuk pembelajaran dengan menggunakan pendekatan kontekstual. Hal ini dapat dijelaskan sebagai berikut:

Pertama, Selama proses kegiatan, santri mengonstruksi dan menemukan pemahamannya sendiri melalui ta'bir dari kitab-kitab salaf yang dijadikan rujukan atas berbagai masalah yang dibahas, sekaligus santri dituntut memberikan solusi sebagai jawaban dari persoalan tersebut dan ini sesuai dengan teori konstruktivisme yang menyatakan bahwa pengetahuan itu dibentuk sedikit demi sedikit kemudian dikonstruk melalui pengalaman nyata. Kedua, dalam babtsul masail santri dituntut untuk sedalam mungkin memahami materi atau persoalan yang sedang dibahas. Untuk memahami soalan tersebut santri dapat bertanya kepada teman sejawatnya sehingga santri memiliki persepsi atas persoalan yang akan dikaji dengan harapan antara ta'bir yang digunakan yang diambil dari berbagai kitab kuning bisa sesuai dengan

\footnotetext{
${ }^{20}$ Kadir, 'Konsep Pembelajaran Kontekstual Di Sekolah', 25. 195
} 
persoalan yang dibahas. Proses seperti ini merupakan bentuk dari karakteristik pembelajaran kontekstual yang kedua yakni inquiri. Menurut pulungan ${ }^{21}$ dalam proses pembelajaran siswa diharapkan dapat memperoleh pengetahuanya bukan hanya melalui fakta-fakta dan teori melainkan melalui beberapa siklus; 1) observasi 2) bertanya 3) mengajukan dugaan 4) pengumpulan data dan kesimpulan.

Ketiga, ketika kegiatan bahstul masail berlangsung para peserta yang sebelumnya telah memperoleh deskripsi masalah dapat menanyakan ulang kepada sail perihal soalan tersebut agar informasi yang diperoleh oleh santri utuh dan tidak sepotong. Sisi lain, para peserta bahstul masail yang terdiri dari beberapa kelompok ini dapat saling bertanya dan menyanggah argumen atau dalil yang dikemukakakn oleh satu kelompok. Ini dilakukan agar dalil yang dipakai bisa dipertanggung jawabkan dihadapan mubarrir dan mushohbih. Bertanya atau questioning merupakan karakteristik pembelajaran kontekstual dimana melalui bertanya siswa bisa menggali informasi seputar pengetahuan yang dipelajari. Bagi siswa bertanya merupakan bagian penting dalam melakukan inkuiri, yaitu menggali informasi, menginformasikan apa yang sudah diketahui, dan mengarahkan perhatian pada aspek yang belum diketahuinya.

Keempat, karakteristik pembelajaran kontekstual adalah masyarakat belajar atau learning comunity, dimana siswa didorong untuk belajar secara kelompok agar tumbuh sisi afektif dalam diri siswa. Begitu pula sebelum pelaksanaan kegiatan bahstul masail santri terlebih dulu dibagi menjadi beberapa kelompok dan masing-masing kelompok terdiri dari 3-4 santri. Kelima, santri yang menjadi peserta bahstul masail adalah santri yang sebelumnya mendapatkan materi dasar tentang metode memahami kitab kuning. Pengetahuan dasar inilah yang kemudian dijadikan alat untuk mencari ta'bir dalam kitab kuning sebagai rujukan dalam kegiatan bahstul masail santri. Selain itu, setiap selesai pelaksanaan bahstul masail para peserta melalui notulen mencatat dan mebukukan hasil bahstul masail yang telah dirumuskan oleh mubarrir

${ }^{21}$ Nellyati Pulungan, 'Penerapan Pembelajaran Kontekstual Untuk Meningkatkan Penguasaan Konsep Dan Kecakapan Hidup Pada Materi Ekosistem Di Mtss AlWashliyah Lhokseumawe', Jurnal Edukasi dan Sains Biologi 3, no. 1 (12 January 2016): 2, http://jfkip.umuslim.ac.id/index.php/jesbio/article/view/36. 
dan telah disepakati bersama. Seperti ini merupakan bentuk karakteristik pembelajarn kontekstual yang berupa refleksi.

Keenam, salah satu unsur yang harus ada dalam kegiatan bahstul masail adalah mushohbih dan mubarrir. Mushobih adalah orang yang membirikan legalitas atas jawaban-jawaban yang dirumuskan oleh mubarrir dan mushohih merupakan orang yang berkompeten di bidangnya. Dan untuk menambah wawasan para peserta terhadap persoalan yang dibahas seringkali mushobhib dan tim ahli didatangkan dari luar pondok. Di sini para santri dapat mencontoh atau menjadikan rule model karena keahlian dan kedalaman ilmu mereka.

Ketujuh, adalah penilaian yang dilakukan oleh ustadz terhadap para santri dalam proses Bahtsul Masail. Aspek yang dinilai adalah bagaimana santri menyampaikan argumennya, ketepatan ta'bir dengan persoalan yang dibahas serta pemahamannya terhadap ta'bir yang diajukan sebagai hujjah. Kegiatan penilaian dilakukan oleh ustadz atau santri senior yang ditunjuk sebagai mushobih selama kegiatan bahstul masail berlangsung. Beberapa hal yang menjadi acuan dalam penilaian terhadap santri adalah kualitas jawaban yang diberikan oleh santri yang meliputi; keakuratan ta'bir, kelogisan argumen, dan kevalidan maraji' (teks kitab yang dipelajari) yang diajukan, cara mengungkapkan isi kitab dengan mudah dipahami oleh peserta Babtsul Masa'il, serta kualitas pertanyaan atau sanggahan yang disampaikan. Sisi lain dari penilaian terhadap santri peserta bahstul masail adalah pemahaman terhadap teks bacaan, kebenaran dan ketepatan santri dalam membaca dan menyimpulkan isi teks yang menjadi bahasan atau rujukan. Beberapa aspek tersebut sangat penting untuk mengukur kemampuan santri dalam proses bahstul masail. Hal ini dikarenakan peserta yang memiliki pemahaman yang baik terhadap kitab kuning dan sekaligus mampu menyampaikan dengan tepat akan dipertimbangkan oleh mubarrir dan mushobih untuk dijadikan sebuah pilihan jawaban atas persoalan yang dikaji.

Bahtsul Masail merupakan forum diskusi yang sifatnya dinamis dan demokratis. Dikatakan dinamis karena persoalan-persoalan yang dibahas selalu aktual dan kontemporer. Mengikuti perkembangan zaman. Demokratis karena dalam forum Bahtsul Masail tidak 
membedakan antara santri senior, pengurus, maupun ustadz bahkan kyai. Namun dalam forum Bahtsul Masail yang patut diikuti adalah pendapatnya para fuqoha' yang paling kuat dan bisa dipertanggung jawabkan.

Dari analisis penulis, dari segi pembelajaran, proses, dan karakteristiknya bahwa kegiatan Bahtsul Masail yang dilaksanakan oleh santri pondok pesantren Al-Muhibbin merupakan pendekatan pembelajaran kontekstual.

\section{Kesimpulan}

Dari hasil penelitian tentang implementasi pembelajaran kontekstual (Contextual Teaching Learning) dalam kegiatan bahstul masail santri di pondok pesantren Al-Muhibbin Bahrul Ulum Tambakberas Jombang dapat disimpulkan:

1. Kegiatan bahstul masail santri di pondok pesantren alMuhibbin Bahrul ulum Tambakberas Jombang merupakan kegiatan ektrakurikuler yang bersifat ilmiah dan diikuti oleh semua jenjang santri dan dilaksanakan setiap satu bulan sekali. Sedangkan tujuan kegiatan bahstul masail santri ini adalah untuk mengasah kemampuan santri baik segi pemahaman, cara penyampaian dan memberikan jawaban atas persoalan persoaln yang timbul di masyarakat sekitar. Secara teknis, kegiatan ini diawali dengan memberikan permasalahan berikut deskripsinya yang sudah dibuat oleh panitia yang kemudian didistribusikan kepada para peserta bahtsul masail. Waktu yang diberikan sekitar dua samapai tiga minggu sebelum dilaksanakan kegiatan bahtsul masail.

2. Dilihat dari prosesnya, kegiatan bahstul masail santri yang dilaksanakan oleh santri Al-Muhibbin Bahrul Ulum Tambakberas Jombang ini merupakan bentuk implementasi dari pendekatan pembelajaran kontekstual (Contekxtual Teaching Learning), dimana aktifitas belajar-mengajar yang berpusat pada siswa/ santri.

3. 


\section{Referensi}

Komalasari, Kokom.. Pembelajaran Kontekstual konsep dan Aplikasi. Bandung: Refika Aditama. 2010

Qomar, Mujamil. Pesantren: dari transformasi metodologi menuju demokrasi institusi. Jakarta: Erlangga. 2005

Sunhaji. Strategi Pembelajaran: Konsep dan Aplikasinya. Jurnal Pemikiran Alternatif Pendidikan, Vol. 13, No. 3. 2009

Dhofier, Zamakhsyari. Tradisi pesantren: studi pandangan hidup kyai dan visinya mengenai masa depan Indonesia. Cet. 8 rev. Jakarta: LP3ES, 2011.

Haedari, M. Amin, ed. Masa Depan Pesantren: Dalam Tantangan Modernitas Dan Tantangan Kompleksitas Global. Cet. 2. Jakarta: IRD Press, 2006.

Hasan, Nur. 'Model Pembelajaran Berbasis Pondok Pesantren Dalam Membentuk Karakter Siswa Di Pondok Pesantren Raoudhotut Tholibin Rembang Jawa Tengah'. Wahana Akademika: Jurnal Studi Islam Dan Sosial 3, no. 2 (2016): 92-110.

Hidayatullah, M. Furqon. Pendidikan karakter: membangun peradaban bangsa. Surakarta: Yuma Pustaka, 2010.

Ilmy, Alfi Najmatil, Abd Hamid Wahid, and Chusnul Muali. 'Urgensi Keterlibatan Wali Asuh Dalam Dinamika Pendidikan Di Pesantren'. Jurnal Pendidikan Agama Islam Journal of Islamic Education Studies) 6, no. 1 (17 July 2018): 44-66. https://doi.org/10.15642/jpai.2018.6.1.44-66.

Kadir, Abdul. 'Konsep Pembelajaran Kontekstual Di Sekolah'. Dinamika Ilmu 13, no. 1 (1 June 2013). https://doi.org/10.21093/di.v13i1.20.

Lexy J, Moloeng. Metodologi penelitian Kualitatif. 29th ed. Bandung: Rosdakarya, 2011.

Mardini. 'Pengaruh Pembelajaran Kontekstual Dan Konvensional Terhadap Keterampilan Komunikasi Terapiutik Ditinjau Dari Tingkat Pengetahuan Awal.' Universitas Sebelas Maret, 2008.

Muslich, Masnur. KTSP: pembelajaran berbasis kompetensi dan kontekstual, panduan bagi guru, kepala sekolah, dan pengawas sekolah. Jakarta: Bumi Aksara, 2007. 
Paturohman, Irfan. 'Peran Pendidikan Pondok Pesantren Dalam Perbaikan Kondisi Keberagamaan Di Lingkungannya.(Studi Deskriptif Pada Pondok Pesantren Dar Al-Taubah Bandung)'. Jurnal Tarbawi 1, no. 1 (2012).

Pulungan, Nellyati. 'Penerapan Pembelajaran Kontekstual Untuk Meningkatkan Penguasaan Konsep Dan Kecakapan Hidup Pada Materi Ekosistem Di Mtss Al-Washliyah Lhokseumawe'. Jurnal Edukasi dan Sains Biologi 3, no. 1 (12 January 2016). http://jfkip.umuslim.ac.id/index.php/jesbio/article/view/36.

PWNU JATIM. Petunjuk Pelaksanakan Babtsul Masa'il. Surabaya: PWNU, 1982.

Rijal, Akh Syaiful. 'Pemakaian Kitab Kuning Dalam Meningkatkan Mutu Pembelajaran Fiqh Di Madrasah Tsanawiyah Berbasis Pesantren Di Pamekasan'. Muslim Heritage 2, no. 2 (1 January 2018): 293-316.

https://doi.org/10.21154/muslimheritage.v2i2.1113.

Rudiyanto, Moh. “'The Implementation of Contextual Teaching and Learning (CTL) in English Class'. Jurnal OKARA 2 (2009).

Saleh, Marhamah. 'Strategi Pembelajaran Fiqh Dengan Problem-Based Learning'. Jurnal Ilmiah Didaktika: Media Ilmiah Pendidikan Dan Pengajaran 14, no. 1 (1 August 2013). https://doi.org/10.22373/jid.v14i1.497.

Siradj, Said Aqiel, Marzuki Wahid, Suwendi, and Saefuddin Zuhri, eds. Pesantren Masa Depan: Wacana Pemberdayaan Dan Transformasi Pesantren. Cet. 1. Bandung: Pustaka Hidayah, 1999.

Taylor, Steven J., Robert Bogdan, and Marjorie L. DeVault. Introduction to Qualitative Research Methods: A Guidebook and Resource. Fourth edition. Hoboken, New Jersey: John Wiley \& Sons, Inc, 2016.

Zahro, Ahmad. Tradisi Intelektual NU: Lajnah Babtsul Masa'il, 1926-1999.

Cet. 1. Yogyakarta: LKiS, 2004. 